\title{
RECENT PROGRESS IN OUR KNOWLEDGE OF PARASITIC WORMS AND THEIR RELATION TO THE PUBLIC HEALTH.
}

\author{
By WILLIAM NICOLL, M.A., D.Sc., M.D., D.P.H. \\ (London School of Tropical Medicine.)
}

TEN years ago I made an attempt to summarize briefly the advances which had been made in our knowledge of parasitic worms during the preceding few years. The interval has witnessed much upheaval and interruption of scientific labour, but nevertheless a very considerable amount of work on the subject has been accomplished. The nature of this does not appear to have been influenced to any exceptional extent by the war.

During this period a terse but useful summary of the more outstanding recent parasitological work has been published by Faust who deals with the subject mainly from its zoological aspect; while the chief publications of medical interest have been succinctly reviewed by Leiper. In the following notes I propose to deal with the subject in somewhat greater detail particularly in its relation to the public health.

One might have anticipated that in a country such as France the preparation and publication of scientific papers would have been grievously hampered by war conditions but that was certainly far from being the case, for French workers, indeed, are excelled only by British and Americans in the quantity and quality of their output of helminthological literature. Russia and Germany are, as might have been expected, a considerable distance behind, while the only other countries in which any outstanding work on parasitic worms has been done are Brazil and Japan.

Britain has certainly been fortunate in possessing such workers as Leiper, Beddard, Baylis, Boulenger, Clayton Lane (India) and T. H. and S. J. Johnston (Australia), but there has been until quite recently a comparative dearth of younger helminthologists. America has been much better supplied in this respect for, in addition to men of such well-established reputation as Cort, Hall, Ransom and Faust, others such as Van Cleave, Cooper, G. A. MacCallum and Larue have produced work of a high order.

The Frenchmen who, in my opinion, have contributed most largely to the science of helminthology have been Seurat, Dévé, Railliet, Henry and, as a physiologist, Fauré-Frémiet. The Russians who appear to have done most useful work are Skrjabin and Cholodkowski, while Germany has been most ably represented by Fülleborn, Martini and Fibiger. Travassos in Brazil and Yoshida in Japan complete the list of the most outstanding names. This list, 
however, does not include the names of many able contributors whose work will be referred to later.

In referring to Faust's review I am struck with the fact that he makes no mention of such names as Hall, Fülleborn, Baylis, Clayton Lane, Dévé and Fibiger, while including the names of others whose claims even to be regarded as helminthologists are, to say the least, obscure. We may take it, however, that this is, as may be, a matter of opinion.

There can be no doubt that during the past ten years America has drawn well ahead of all other countries, with the possible exception of Britain, in the matter of helminthological work. This might be attributed to some extent to the war which did not upset American economic conditions so seriously as it did those of Europe. Another reason perhaps is that, helminthologically speaking, America is a new and largely untouched terrain. Its great faunistic wealth implies a correspondingly great variety of helminth forms. The chief reason, however, is that Americans have been the first to realize to the full the great importance of helminthology in veterinary medicine and agriculture. The work of Hall and of Ransom, for instance, has been devoted essentially to this side of the subject. Another department in which Americans have taken a foremost place is that of bibliography, in which connection the names of Stiles and Hassall are outstanding. It is somewhat gratifying to find that the subject of veterinary helminthology has begun to receive a little more of the attention which it greatly needs in this country and the colonies. It has, of course, for some time held a fairly prominent position in Australia thanks largely to the occurrence there of worm nodule disease in cattle but even there it has not to any great extent been organized as it properly should be.

In view of their great prevalence and economic importance it is not surprising that Nematode parasites have received considerably more attention than any other group of parasitic worms. In consequence, we find that such men as Seurat, Hall, Fülleborn, Baylis, Leiper, Railliet and Henry have devoted the greater part of their attention to this group. Cestodes have been dealt with most extensively by Beddard, Harvey Johnston, Hall and Skrjabin, while the chief work on Trematodes has been done by Cort, Faust, Yoshida, Leiper, S. J. Johnston and myself.

The bulk of zoological literature relating to parasitic worms deals naturally with structure and classification. The elaboration of means of accurate identification and ready classification is one of the primary objects of all zoological work. Neglect of this has led in the past to a certain amount of confusion in experimental investigation. The identification of adult forms is in the main a comparatively easy task. The identification, however, of larval forms, particularly of many Nematodes, is much more difficult. On that account reliable work on larval structure and development is of the utmost importance, especially from the point of view of preventive medicine. It is only when the zalient features of the life-histories of these parasites are accurately known that we can hope to attain administrative control over the diseases to which 
they give rise. In no department of preventive medicine is the statement that prevention is more useful than cure of greater applicability than in Helminthology, and no more striking instances of this could be wished for than such diseases as Ancylostomiasis and Bilharziasis.

The importance of attention to minute structural and anatomical detail is well instanced by recent work on the Sclerostome parasites of horses. Where not many years ago only a dozen or so ill-defined and much-confused species were recognized, now there exists a large family with numerous genera and species. While this involves a much extended and possibly more cumbrous nomenclature it yet creates a greater simplification and precision of detail.

On that account one must welcome such work as that of Beddard which though inclined to be prolix in certain respects is yet of the greatest fundamental value. His work is probably amongst the best which has been done on Cestodes in this country. Another contribution on Cestode structure which appears to be of considerable importance is that of La Rue on the Cestode family Proteocephalidae. Although this work is to a large extent revisionary it constitutes a valuable summary of our knowledge of a somewhat unusual group. Of a similar character is Douthitt's monograph on the Anoplocephalid family of Cestodes. This is of great importance to those who may be concerned with the tapeworm parasites of horses.

A useful summarizing work is that of Krause on the Hemistomes, a group of Trematodes which is of considerable zoological interest though not of much pathological importance. Of equal merit and of much greater economic importance is Stunkard's monograph on the Polystomidae, Aspidogastridae and Paramphistomidae of North America. Of some interest, too, is the embryological work of Lepeskin on the ovogenesis of Zoogonus mirus, a peculiar ovoviviparous Trematode parasite of Mediterranean fishes. This parasite lends itself particularly well to such study and has been the subject of previous similar work by von Hofsten and others.

These constitute perhaps the most extensive single works on Cestode and Trematode anatomy. On Nematode structure the work is considerably more voluminous but one can deal here with only a very restricted selection. Perhaps the most outstanding monograph is that of Martini on the anatomy of Oxyuris curvula, the large threadworm of the horse. Martini's histological work is, of course, well known and this monograph constitutes a fitting successor to his earlier work on Ascaris. Of somewhat similar nature is Deineke's histological researches on the nervous system of Ascaris megalocephala. The work of Neveu-Lemaire on the reproductive organs of the Metastrongylidae is also deserving of special mention as is that of Zacharias on the finer structure of Ascaris from a cytological standpoint. Seurat's monograph on the parasitic Nematodes of Northern Africa (1920) and Khalil's revision of the Nematode parasites of Elephants (1922) are two of the most important recent systematic works on Nematodes.

Of more practical importance to the economic helminthologist is Hall's 
review of the Nematode parasites of rodents, a subject which has acquired extraneous medical interest as a result of Fibiger's investigation on rat cancer.

Ascaris lumbricoides has formed the subject of a fairly important work on chemical physiology by von Kemnitz, but this is of little intrinsic interest to helminthologists.

At the present time the life-history and mode of development of parasitic worms are most important subjects of research and discussion both from a zoological and from a medical point of view. The complicated life history of some of these worms is at times baffling and requires much patience and persistence in its elucidation.

Without doubt, during the past decade several discoveries of the very highest importance have been made. Chief amongst these must be placed the work on Bilharziasis. This subject has called forth a greater bulk of literature than any other in Helminthology. Ten years ago we owed a large part of our knowledge and opinion on the subject to Looss but he, curiously enough, formed the conclusion, based apparently on negative observations and experiments, that no intermediate host was concerned in the life-history of Bilharzia (Schistosoma) haematobia and that the larval parasite after its escape from the eggshell was able to re-infect the human subject in the miracidial or first larval stage by direct penetration through the skin. Such a conclusion was, needless to say, opposed to all previously acquired ideas of the life-history of digenetic Trematodes though the fact that the Schistosomes are so sharply differentiated structurally from all other digenetic Trematodes lent colour to the supposition that their life-cycle might also be radically different. The subject, however, was of such great economic and medical importance that this conclusion could not be accepted without very much more definite and irrefutable evidence. Such evidence has been accumulatively forthcoming from various quarters, particularly Japan and Egypt.

It is impossible, in a brief summary, to enter into full details of this voluminous work. A recent review of current knowledge and progress in the matter has been written by Fairley (1919) but the most comprehensive account is contained in Leiper's original reports on the work of the Bilharzia mission in Egypt (1915-1918). This report will probably take rank as the greatest helminthological classic since Looss's monograph on Ancylostoma. Though it be true that some of Leiper's results were forestalled by Japanese investigators (e.g. Miyairi and Suzuki, 1914) and that he may be indebted to them for suggestive ideas, yet the credit of the completed work is undoubtedly to a large extent his. It has been shown definitely that an intermediate molluscan host plays a necessary part in the life-cycle of the parasite. The important feature remains, however, that infection can take place through the intact skin. The chief point for consideration is the interpolation of the intermediate host for, from a prophylactic point of view, this affords a useful if not particularly vulnerable point of attack in the life-cycle. Further reference will be made to this. 
Bahr and Fairley (1920) have confirmed Leiper's opinion that Schistosoma mansoni and $S$. haematobium are distinct. They found that the molluscan intermediate host, Planorbis, can only be infected with Schistosoma mansoni, while Bullinus, another intermediate host, is not susceptible to infection with that species. Moreover, the cercariae from Planorbis give rise to the rectal form of Bilharziasis while those from Bullinus produce the urinary form.

Another important Trematode, the life-history of which has been recently elucidated, is Fasciolopsis buski. Our knowledge of this we owe to Nakagawa (1921) who has found that the miracidial larva encysts in species of snails of the genera, Limnaea, Planorbis and Segmentina, especially Planorbis coenosus and Segmentina largillierti. The cercariae, like those of Fasciola hepatica, encyst on grass.

Amongst other works on Trematode life-histories mention must be made of Faust's valuable work on American and South African forms, Cort's studies on North American larval Trematodes and Jegen's monograph on Collyriclum $f a b a$, a Monostome parasite of singing birds.

The most important work on Cestode development is that of Janicki and Rosen (1917) on the life-cycle of Dibothriocephalus latus, a work which has evidently given rise to some controversy between the collaborateurs. Rosen, in a later publication $(1918,1919)$, maintains that the first intermediate hosts of the broad tapeworm are the Copepod Crustaceans, Cyclops strenuus and Diaptomus gracilis. In addition he found that Cyclops also functions as the primary intermediate host of Ligula simplicissima, a common tapeworm of aquatic birds. Galli-Valerio (1919) has also added some notes on the development of the broad tapeworm. Another tapeworm of the same group, Schistocephalus solidus, has been shown by Nybelin (1919) to pass its larval stage also in species of Cyclops (C. serrulatus and C. bicuspidatus).

Perhaps the most interesting work on this group of tapeworms, however, is that of Okumura (1919) on Sparganum mansoni, a not uncommon tapeworm parasite, in its larval stage, of man in the East. According to Okumura the onchosphere or first larval stage of this parasite develops in the Copepod, Cyclops leuckartii. When this is ingested by a mouse or a frog the onchosphere penetrates the intestinal wall and develops into the plerocercoid stage in the body cavity. This plerocercoid, when swallowed by a dog, develops into an adult tapeworm in the dogs' intestine just as the human Sparganum does when similarly ingested, and the adult tapeworms resulting from such infections are, according to Okumura, identical.

The interesting subject of the life-history of Hymenolepis nana has been taken up by Joyeux (1920). He has confirmed the belief that this tapeworm infects without the intervention of an intermediate host but he was unable to infect rats by means of eggs from human cases thus apparently proving that the human parasite is specifically distinct from the morphologically similar Hymenolepis murina which normally infects rats. In 1911 Minchin and Nicoll found a cysticercus larva in the rat flea (Ceratophyllus 
fasciatus) which they considered to be the larva either of Hymenolepis murina or of some yet unrecognized species. Such a species has now been discovered by Baylis (1922) and named Hymenolepis longior.

Of some interest is the record by Parisot and Joyeux (1920) and Blanc and Caminopetros (1921) of the discovery of the larvae of two tapeworms of the cat (Dipylidium trinchesei and D. chyzeri).

In contrast to the meagre amount of work on Cestode life-history is the large volume of interesting researches on Nematode larval development. Most prominent amongst this is Looss's monograph on the life-history of the hookworm. This work, however, is now so generally known and has been so extensively reviewed and commented upon that no further criticism appears necessary. One point nevertheless, of some importance has arisen, namely the alleged heterogenesis or alternating life-cycle of Ancylostoma. Surprising as it may seem to anyone with a working acquaintance with hookworm development this point has been raised anew by more than one observer but in view of the very large consensus of confirmation of Looss's work it is to be hoped that the matter has been finally settled.

Of more recent date is the work of Fauré-Fremiet on the embryological development of Ascaris. Extending over a number of years this work was published in the form of a large monograph in 1913.

The most important work on Nematode life-history is, possibly, that on the life-history of Ascaris, investigations which probably rank next in importance to those on Bilharzia. The names most closely associated with this work are those of Stewart, Ransom, Foster and Yoshida. Stewart, experimenting with rats and mice, found that the infecting larvae pursued a migratory course in the body of the experimental animal somewhat similar to that followed by the larvae of Ancylostoma, namely a passage through the intestinal wall, transference to the lungs via the blood stream and a migration thence via the trachea into the intestine again. The fact that these larvae, after they had again reached the intestine, did not develope further there but were passed out with the intestinal contents led Stewart at first to form the hypothesis (abandoned later) that rats and mice constituted a sort of intermediate host for the Ascarids. (It may be noted that no species of adult Ascaris has ever been recorded as a natural parasite of rats or mice.) This view was not accepted by Ransom and Foster (1919) who have demonstrated that a similar migratory course is pursued by larval Ascarids in infecting their natural host, e.g. Ascaris lumbricoides in the pig. It is thus evident that there is some resemblance between the invading stages of Ascaris and Ancylostoma, the essential point of difference in the life-history, however, being that Ascaris has no external free larval life.

In addition to his work on the life-history of Ascaris Ransom has added considerably to our knowledge of the life-history of two other Nematode parasites, namely Habronema muscae and Gongylonema scutatum, both of which are of decided importance in veterinary helminthology. In the case of 
the former Ransom has demonstrated that the larval Nematode found as long ago as 1859 by Carter in the common house-fly in Bombay and named by him Habronema muscae is actually the larval stage of a parasite of the horse, closely allied to a similar horse parasite, Spiroptera microstoma described in 1866 by Schneider. The occurrence of this larval Nematode in the house-fly and the stable-fly (Stomoxys calcitrans) has also been recorded in Australia by Harvey Johnston (1912).

The life-history of this parasite is one of the most remarkable which has been brought to light within recent years. It furnishes yet another instance of the important part which house-flies play in the transmission of disease. So far as one can judge from observation and experiment the life-history appears to proceed on the following lines. The eggs or larvae of Habronema, occurring in the horse manure, are ingested by the larvae of the house-fly. During the metamorphosis of the fly the larval worms find their way into the Malpighian tubules and thence in the adult fly they migrate into the proboscis. When the fly applies its proboscis to an open sore or to the lips or conjunctivae of the horse the larval worms escape from the fly's proboscis and invade the abraded tissue. Thence the worms migrate through the body of their host and eventually find their way into the intestine. Infection with this worm is thus curiously correlated with the occurrence of "summer sores." We owe the elucidation of this remarkable life-history chiefly to Railliet and Henry (1915), van Saceghem (1917), Hill(1918), Teppaz (1919) and Roubaud and Descazeux (1921).

The most recent discovery of prime importance to human medicine is that of the life-history of Loa (Filaria) loa. This is the result of some excellent experimental work by A. and S. Connal (1922) in Lagos. Following one of Manson's intuitive suspicions they devoted attention to the Tabanid flies, Chrysops silaria and C.dimidiata in which they have been able to demonstrate that the worm passes its larval life. The larvae develop in the abdominal muscles and connective tissue of the fly and eventually in their infective state migrate to the fly's proboscis.

The life-history of another worm of the Spiroptera group, Gongylonema scutatum, a parasite of sheep and cattle, has also been dealt with by Ransom and Hall $(1915,1917)$ who found that the larvae live in dung-beetles of the genera Aphodius and Onthophagus and in the croton bug (Ectobia germanica). The allied parasite, Gongylonema pulchrum, of the pig also develops in the croton bug. The first observations on the larval host of worms of this group were made by Leuckart (1867) and Marchi (1871) in the case of the rat parasite, "Spiroptera" obtusa, the larva of which was found to occur in a beetle, Tenebrio molitor.

Another strikingly able paper is that of Veglia on the anatomy and lifehistory of the Nematode, Haemonchus contortus. The developmental history of this important parasite of sheep is worked out in great detail and the result is a model of what such experimental investigations should be. It is undoubtedly one of the best pieces of work of its kind. 
Martin has published an interesting paper on the conditions of embryonic development of parasitic Nematodes in general, while Kautzsch has dealt at length with certain anomalies in the development of Ascaris. With regard to "free living" Nematodes the most economically important work appears to be that of Stift on the life-history of root Nematodes.

Turning now to what is, from a medical point of view, the subject of greatest interest, namely the relation of parasitic worms to disease we find that quite an extensive literature has accumulated, much of it being of the very highest order. First in point of importance and by reason of the large amount of excellent research work done in regard to it is Bilharziasis. While not having quite such a widespread distribution as the hookworms or the filarial worms the Bilharzia species are the cause of some of the most serious pathological conditions originated by any worm parasite, and the gravity of such conditions is accentuated by the fact of their comparative intractability to medical treatment.

Although the disease has been known apparently from very ancient times it is only within the past seventy years that its causal agent has been definitely recognized. The worm is thus a slightly more modern acquaintance than its rival Ancylostoma duodenale though both, so far as may be judged from historical evidence, were familiar to the people of ancient Egypt some thousands of years ago (Khalil).

Much as one may feel tempted to enter on a detailed discussion of the administrative measures, necessary or advisable for the control of this disease, it seems to me that the conclusions reached by Leiper sum up the position sufficiently clearly. These have been quoted by more than one reviewer but their administrative importance justifies further repetition. They are that (1) transient collections of water are quite safe after recent contamination; (2) all permanent collections of water such as the river Nile, canals, marshes and birkets are potentially dangerous, depending upon the presence of the essential intermediate host; (3) the removal of infected persons from a specified. area would have no effect, at least for some months, in reducing the liability to infection (i.e. of other persons), as the intermediate hosts continue to discharge infective larval forms for a prolonged period; (4) infected persons cannot reinfect themselves or spread the disease directly to others. They could only convey the disease to those parts of the world where suitable local molluscs were present to act as intermediate hosts; (5) infection actually takes place both by the mouth and through the skin; (6) infection in towns is acquired from unfiltered water which, in addition to filtered water, is still supplied even in Cairo though it is delivered by a separate system of pipes; (7) eradication can be effected without the cooperation of infected individuals by destroying the molluscan intermediate hosts.

In these respects Leiper's conclusions differ radically from those of Looss, the pivotal point being, of course, the infective stage of the worm (cercaria instead of miracidium). They are, undoubtedly, of the very highest importance 
to all sanitarians who have to deal with the problem of Bilharzia prevention and eradication.

In the nature of constructive administrative policy Leiper adds: "If a campaign against bilharziasis were commenced on the lines here proposed it is evident that the whole scheme should be under the charge of a medical zoologist who should be attached, not solely to the Public Health service as in Ancylostoma campaigns, but also to the Department of Irrigation. In this way, only, could the full and continuous effect of the present administrative control of the Nile water be brought to bear upon the Bilharzia-carrying molluscs so as to ensure their permanent eradication from lands now heavily infected and their exclusion from new areas about to be reclaimed."

Of practical local measures which might, with advantage, be adopted Leiper suggests that unfiltered water from potentially infected sources such as canals, ditches and birkets would be rendered safe (1) if stored beyond the survival period of the cercariae, i.e. for at least forty-eight hours; (2) if heated to $50^{\circ} \mathrm{C}$, a temperature at which the cercariae are immediately killed; (3) if previously treated with chemicals which are lethal to the cercariae, e.g. chlorinated lime, benzoic acid, etc.

Other noteworthy and important contributions to our knowledge of Bilharźiasisare those of Katsurada (1913), Looss and Kartulis (1913), Miyagawa (1913), Miyairi and Suzuki (1914), Ogata (1914), Narabayashi (1914), Cawston (1918), Liston and Soparkar (1918), Lutz (1920), Bahr and Fairley (1920) and Cort (1921). Of these the last mentioned is of most interest. Cort has been able to supply in the case of Schistosoma japonicum, in a fairly complete form, a knowledge of the course pursued by the parasites from their entry into the body till they reach their ultimate habitat in the portal veins. After penetrating the skin or mucous membrane the larvae are carried by the veins or lymphatic vessels to the heart, whence they are conveyed to the lungs. Thence there appear to be two alternative courses. The first is via the pulmonary veins back to the heart and thence to the hepatic-portal system. In the second and possibly the more frequent course the larvae penetrate the substance of the lungs. Thence, via the posterior and anterior mediastina, they migrate to the peritoneal cavity where they bore their way into the liver and so reach the hepatic-portal venous system. It is evident that in this complicated migration pathological effects may be produced in the lungs, liver, etc., in addition to the more characteristic pelvic and urinary symptoms.

Interesting serological work in relation to Bilharzia infection has been carried out by Fairley (1919) who has prepared a specific antigen from the liver of molluscs infected with Bilharzia cercariae. More recent work on the same subject has been published by Le Bas (1922).

It is a matter of some significance that indigenous cases of Bilharziasis have recently been recorded in Europe (Southern Portugal) by França (1921) and others, the intermediate host there being a subspecies of Planorbis corneus. 
The next most important subject is Filariasis in its multiplicity of forms. This has called forth almost as voluminous a literature as Bilharziasis, but no one species has received such exhaustive treatment as Schistosoma haematobium, nor is the intrinsic value of the work comparable with that done on Bilharzia. The most considerable contribution is probably that of Manson-Bahr (1912) on Filariasis and Elephantiasis in Fiji. Fülleborn (1913) gives an up-to-date account of human Filariasis in its various aspects and in the same year he published an exceedingly useful monograph on the differential diagnosis of Microfilariae. Meinhof (1913) has dealt pretty thoroughly with the morphology of Loa loa and its clinical manifestations. A new human microfilaria (M. nuda) has been observed by Rodenwaldt (1914) in Togoland while Biglieri and Araos (1917) have also described a new human Filaria ( $F$. tucumani) from South America. La Cava (1916) has recorded the first autochthonous case of elephantiasis in Europe caused by $\boldsymbol{F}$. bancrofti in the province of Treviso, Italy, while Skrjabin (1917) has described a new species of ocular Filaria (Loa extraocularis) from man. Yorke and Blacklock (1917) have made useful observations on the periodicity of Microfilaria nocturna and Ruiz Arnim (1916) contributes a lengthy monograph on primary tropical lymphectasis. Wirth's paper (1917) on the Filariae of horses is also rather useful.

The interesting subject of Filariasis in dogs (Dirofilaria immitis) has recently received renewed attention with the result that much light has been thrown on the life-history of this dangerous parasite. For this we are indebted chiefly to Fülleborn (1912) and Saisawa (1912) who have shown that the worm passes its larval stage in the mosquitos, Stegomyia fasciata and Anopheles maculipennis. More recently Breinl (1921) has found that the worm may also complete its larval development in the dog-fleas, Ctenocephalus canis and C. felis.

Bernard and Bauche (1913) have further concluded that Stegomyia fasciata also serves as the intermediate host of the subcutaneous Filaria of the dog (Dirofilaria repens).

Ancylostomiasis has, until recently, not attracted quite so much attention during the past decade as it did previously. This is in part due to the fact that Looss in 1911 set the stamp of his authority on many points that had for some time been controversial and in part to the fact that effective means of treatment have been elaborated and carried into practice in various parts of the world. In spite of this the disease remains and will remain one of the most serious with which sanitarians, particularly in the Tropics, have to deal.

Fülleborn (1914) has contributed an interesting and useful paper on the biology and mode of infection of Ancylostoma and Strongyloides, while Baermann (1917) has recorded his extensive experience in Java and has dealt with preventive measures at some length. Not the least important part of Baermann's work, however, lies in the fact that he devised an efficient method of isolating hookworm larvae from samples of soil. This method was adopted and elaborated by the American Hookworm Commission in the West Indies. The work of this Commission (Cort, etc., 1921-2) is unquestionably the most 
far-reaching which has been accomplished on the subject since that of Looss in Egypt.

One of the most interesting biological facts revealed by the work of the Commission is that hookworm larvae commonly live in an unensheathed state in the soil. Hitherto it has generally been believed that the unsheathing takes place at the moment the larvae penetrate the skin of their host, though the occurrence of unsheathed mature larvae in experimental cultures must be a matter of fairly common observation. The report also deals with several matters of administrative importance.

Another species of hookworm, Ancylostoma ceylanicum, is dealt with by several authors and its geographical distribution forms the subject of a paper by Ihle (1918).

The matter of next greatest economic importance appears to be Onchocerciasis (worm nodule disease in cattle). This is a subject our knowledge of which is of comparatively recent date. Although the disease has been recognized for many years scientific interest in it dates only from the past twenty years. Curiously enough it is in Australia, the land of imported cattle, that the condition has given rise to most discussion and in consequence the bulk of the work has been done by investigators in Australia. The most considerable contribution to the subject is that of Sweet (1915) who in the course of a tour round the world visited most of the countries in which the disease is known or suspected to occur. Her paper forms therefore a very useful summary of the geographical distribution of the parasite and contains many interesting observations on local conditions as they may affect the spread of the infection. Previously (1912) Harvey Johnston published a summary of existing knowledge on the subject at that time. The most important experimental work, however, is that of Burton Cleland (1914) who attacked the problem in an energetic manner but without solving the mystery of transmission. I have personally (1914) carried out some experiments on the nodules both in vivo and in vitro without any striking result except to demonstrate that the larvae can and do penetrate the thick capsule of the nodule in which they are enclosed and thus get into a situation in which a potential intermediate host may reach them. No intermediate host has, however, been discovered so far and practically no definite clue is available to point the way to a possible lifehistory. The fact that similar worms cause disease in man (Onchocerca volvulus) and in horses (O. caecutiens) gives the subject an economic interest which is not confined to cattle. Rodhain and van den Branden (1916) and Robles (1919) have made interesting contributions to our knowledge of the human form of Onchocerciasis which has received further treatment at the hands of Brumpt (1920), Desoil (1920), Montpellier and Lacroix (1920), and most recently Ouzilleau, Laigret and Lefron (1921). Further remarks on cervical Onchocerciasis of horses have been published by Railliet (1919).

of much greater medical interest and importance is hydatid disease (Echinococcosis). This is another disease which has afflicted Australia in 
perhaps undue proportion, but although a considerable Australian literature on the subject exists most recent work has been done in Europe, chiefly by Dévé. In the course of a very extensive series of experiments he has dealt with a great variety of aspects of the disease both primary and secondary. Most recently he has been especially concerned with experimental echinococcosis of bones and with the disease as it manifests itself in infants, both subjects which appear to be of importance from the point of view of comparative pathology. He has also dealt to some extent with the matter of treatment.

The subject of serological diagnosis of hydatid disease has also engaged a fair amount of attention. This practically dates from the original work of Weinberg and of Welsh and Chapman in 1908. Since then, however, Weinberg (1913) has further elaborated the work which is of great importance as, in addition to its bearing on hydatid disease, it raises the whole question of serum diagnosis in the case of helminths. It is obvious that the method is of significance in the diagnosis of such helminth infections as are not readily diagnosable by ordinary clinical methods.

Another important contribution to our knowledge of echinococcosis appears to be that of Mita (1918) but this work I have been unable to consult.

The occurrence of the adult Taenia echinococcus in dogs in Friesland forms the subject of a monograph by Tenhaeff and Ferwerda (1919).

A subject which has recently come into prominence is that of rat cancer (Spiroptera tumours) with which the name of Fibiger is most intimately associated. He and his colleague, Ditlevsen, conclude that Spiroptera or Gongylonema neoplasticum, as they name the worm, is capable of giving rise to intestinal growths of a true malignant or cancerous character, with metastases. According to Fibiger the larvae of this parasite occur encysted in cockroaches (Periplaneta americana), with which he claims to have infected rats. It should be noted that a number of worms (e.g. Oesophagostomum spp., etc.) cause tumour formation in the intestine of their host but such formation is not necessarily of a malignant character. Bulloch and Rohdenburg (1918), moreover, showed that similar tumours could be produced in rats by introducing a spiny glass ball into the stomach.

Compared with that on Bilharzia recent literature relating to the lungflukes (Paragonimus) is extremely scanty. The most important contributions are those of Ward and Hirsch (1915), Yoshida (1916) and Nakagawa (1916). The first-mentioned consists of a revision and correction of existing morphological knowledge of the species of Paragonimus. Nakagawa was the first to discover the intermediate hosts of the parasite, namely the freshwater crabs, Potamon obtusipes and $\boldsymbol{P}$. dehaanii. Yoshida added two other species of crab, Sesarma dehaanii and Eriocheir japonicus. In these crabs the parasites occur in their encysted cercarial stage, and an earlier intermediate host of the sporocyst stage, probably a mollusc, yet awaits discovery. Yoshida (1916 a) followed the course of the infecting larvae in their final host (dog and cat) experimentally 
and found that they penetrated the stomach or intestinal wall, thus reaching the peritoneal cavity, whence by penetrating the diaphragm and pleurae they reached the lungs. According to Yoshida, therefore, the worms, unlike Bilharzia, reach their ultimate destination, the lungs, by their own migratory efforts, without the aid of the blood vascular system. He does not entirely account for the occasional occurrence of the worms in the brain though he states that "some of the worms may proceed cephalad, taking their course through the loose connective tissue along the oesophagus or the blood vessels." Later experimental work of Yokogawa and Suyemori (1921) on intracranial infection has failed to solve this point so that for the present we must accept Yoshida's supposition as a working hypothesis.

We have now dealt with what are generally considered (from a pathogenic and public health point of view) to be the most important parasitic worms. There remain, however, several others to which at least passing reference must be made. Of these Trichuris trichiurus (Trichocephalus dispar) has probably attracted most attention. It is a worm which in itself is possibly of second-rate pathogenic importance but which as a predisposing agent in serious intestinal affections may play a more definite part than has been generally believed to be the case. There appears to be quite strong evidence to associate it with a form of enteritis (Garin, 1912) and it is certainly suspect as a predisposing factor in cholera (Guerrini, 1915), and dysentery (Brau, 1914). An extensive monograph on the worm has been written by Christoffersen (1913).

There appears some ground for supposing that Trichuris like Ascaris and Ancylostoma pursues a complicated route of invasion in its host, but the only evidence so far reported is that of Neshi (1918) who recorded the finding of a few larvae of $T$. depressiusculus (the whipworm of the dog) in the lungs within twenty-four hours after the ingestion of Trichuris eggs.

Also, according to the observation and opinion of Yokogawa (1921), another allied worm, Trichosomoides crassicauda, the common parasite of the urinary bladder of rats, has a similar migratory course via the lungs, but the route of the larvae from the lungs to the bladder has not been traced. Yokogawa, however, considers that von Linstow's observation in 1874 of young worms in the kidneys and ureters is suggestive that the worms enter the bladder by way of the kidneys. Further investigation, however, is necessary to complete our knowledge of the migratory course in the case of this parasite. Its importance as a pathogenic agent is evidenced by the fact that it may give rise to papillomatous growths in the bladder and apparently also in the kidneys (Löwenstein, 1912).

Allied to Trichuris but of much greater economic importance is the measle worm (Trichinella spiralis). Its frequency and dangerous nature are notorious in many parts of Europe. A comprehensive account of the structure and pathogenicity of this parasite is given by Stäubli (1913), but further researches on the toxic properties of the worm have been made by Flury (1913). 
With regard to Ascaris the only important work is that on its life-history which has already been discussed. Two matters of some medical interest however may be mentioned, namely, the association of Ascaris with reflex epileptiform attacks (Francaviglia, 1915) and with erythema nodosum (Montel, 1916).

Researches on Strongyloides stercoralis have not been numerous but they include the important work of Fülleborn (1914) on the biology and mode of infection of the parasite. It is not altogether remarkable that this worm should have to some extent confused the issue in regard to Ancylostoma, for, in the first place, the two are not infrequently associated and, secondly, the mode of infection is somewhat similar in both cases. In other respects, however, the worms are widely divergent for Strongyloides exhibits the remarkable phenomenon of heterogenesis which has been so often erroneously ascribed to Ancylostoma. Fülleborn's investigations are full of interest.

The important veterinary matter of horse Strongyles has received a considerable amount of attention in this country at the hands of Yorke and Macfie (1918), Boulenger (1916-17) and Leiper (1913). Further references to the pathogenic action of these worms are to be found by Coureur (1915) and Parodi and Widakowich (1918). The latter deal with the mechanical action of the worms in the intestine of their host, while the former is concerned with the general cachetic state which may result. Bang (1913) deals with the subject of infection in young horses, while Leiper records a new Cylicostome from London horses. Horse Oxyurids have received attention from Railliet, Bedel and Donnat (1918) who form the opinion that the presence of the worms is associated with colic and emaciation.

The interesting hypothesis of worms as a cause of appendicitis has received a large amount of attention during the past ten years chiefly on the part of Rheindorf (1920) and of Innes and Campbell (1914). Additional cases are recorded by Sénechal and Engel (1912), Borini (1914), Glines (1916) and Hueck (1913). If the view that Oxyuris and other intestinal worms are a direct or indirect cause of appendicitis can be substantiated it is evident that appendicitis, at least of a certain type, must be regarded as a disease of infection and must therefore be amenable to public health measures for its prevention, a view which Rheindorf strenuously maintains.

The occurrence of "pneumonia" during the course of helminth infection has been brought into much prominence by recent work on Ascaris infection. Ever since Looss's memorable discovery of the lung route of the infecting larvae of Ancylostoma the occurrence of pneumonia symptoms associated with intestinal helminth infection has been fraught with significance. In 1914 I personally recorded the occurrence of fatal pneumonia in dogs undergoing experimental infection with Ancylostoma caninum. At that time I was inclined to ascribe the fatal issue to a superimposed microbial infection with a species of Pasteurella which was isolated from the lungs of the dead dogs by Dr J. A. Arkwright. Both Ransom (1919) and Stewart (1920), however, have definitely concluded that pneumonic symptoms are a regular concomitant 
of Ascaris infection and indeed Stewart indicates that he regarded the onset of such symptoms in his experimental animals as definite evidence that Ascaris infection had taken place. Ransom, moreover, associates the pneumonic disease, known as "thumps" in young pigs, with Ascaris infection and by analogy suggests that many cases of "pneumonitis" in human beings, particularly children, are possibly the result of invasion of the lungs by infecting Ascaris larvae. In view of these observations it is obvious that the indifferent attitude displayed by some people in regard to Ascaris infection must be abandoned.

In addition to the pneumonia caused by migrating larvae, however, pulmonary symptoms may be caused by worms which have their final habitat in the lungs. The best known instance of this in human parasitology is, of course, the lung fluke Paragonimus, but instances in domesticated and other animals are by no means uncommon. Of late years chief attention has been called to the "worm pneumonia" of sheep due, mostly, to the lung-nematode Dictyocaulus filaria. This matter has been dealt with by, amongst others, Blum (1911), Knuth (1912) and Romanovitch and Slavin (1915). It is evidently of no small economic importance.

The toxic effects of parasitic worms is a matter which has called forth a considerable amount of investigation, and with which the name of Weinberg has for some time been associated. Since 1912 his principal contribution to the subject is that, in collaboration with Seguin, on eosinophilia (1914). A certain amount of work, apparently negativing Weinberg's conclusions, has been published but his views have received positive support from the work of Bedson (1913), Paulian (1918), Rachmanov (1914), Pomella (1921), Simonin (1922) and others. The frequent, though not invariable, occurrence of high degrees of eosinophilia associated with helminthic infection is a phenomenon of some import and it appears almost certainly to be correlated in some measure with toxic action. Weinberg and Seguin (1914) and Guerrini (1914) have published some interesting work on this subject.

The association of Strongyloides with dysentery has been dealt with by Noc (1915) in Cochin China. He came to the conclusion that the worm is not absolutely definitely pathogenic, but that it is frequently associated with bacillary and amoebic dysentery and may possibly accentuate the symptoms of these diseases.

A matter of considerable interest and perhaps of some importance is the reported occurrence of Nematodes of the genus Trichostrongylus as parasites of man. Instances have been recorded in India, Egypt and Japan. Species of this genus are not uncommon parasites in ruminants and other mammals, but the most familiar species in this country is that associated with grouse disease (T. pergracilis Cobbold). The first discovery of such worms as human parasites was apparently made by Ogata in 1889 and they were identified by Ijima (1895) as Strongylus subtilis. In 1914, however, Jimbo decided that these worms which are apparently very common parasites of man, and of man only, 
in Japan and Korea represents a distinct species which he named Trichostrongylus orientalis. Other species of this genus which have been reported as occasional parasites in man are T. vitrinus Looss 1905 in Egypt, T. probolurus (Railliet 1896) also in Egypt and T'. colubriformis (Giles, 1892) (which is usually referred to as Strongylus subtilis or $T$. instabilis). It would thus appear that four distinct species of this genus may be occasional or even common parasites of man. Their small size and inconspicuous appearance render their detection a matter involving more than usual care. A somewhat similar, though larger, cattle Nematode, Haemonchus contortus, was reported as a human parasite in Brazil by Magalhaes in 1908. These worms must be taken into account in human pathology as potential causes of anaemia and enteritis.

Another worm of considerable economic importance is the kidney worm of swine (Stephanurus dentatus). This is yet another case in which it has"been demonstrated that infection may take place through the skin (Bernard and Bauche, 1914).

Allied to the rat tumour Spiroptera, to which reference has already been made, is a worm of greater economic importance, namely, Spiroptera (Spirura) sanguinolenta, a not uncommon parasite of dogs in certain parts of the world. Following the work of Grassi in 1888 it was tentatively accepted that the larval stage of this worm occurs in the common cockroach (Blatta orientalis). Seurat (1912), however, maintains that this larva is that of Spirura talpae, a similar parasite of the mole, and that the larvae of $S$. sanguinolenta occur encysted in fowls, hedgehogs and lizards, a somewhat extraordinary variety of intermediate hosts.

The last matter of Public Health interest which need be dealt with here is that of house-flies as carriers of parasitic infection. Since 1911, when I published some experimental observations on this subject, Shircore (1916) and Wenyon and O'Connor (1917) have confirmed these results by observations under natural conditions. Shircore found eggs of Trichocephalus dispar, Taenia saginata, Ancylostoma duodenale, and Ascaris lumbricoides in or on flies from hospital wards in British East Africa. Apparently 10-12 per cent. of these flies were functioning as natural "carriers." Wenyon and $O^{\prime}$ Connor examined the faeces of "wild" flies under natural conditions and found eggs of Taenia saginata, Ancylostoma duodenale, Trichocephalus, Heterophyes and lateralspined eggs of Bilharzia. These observations in conjunction with the classic experiments of Grassi and Calandruccio leave little doubt that house-flies play an actual part in the dissemination of worm infection, particularly of such forms as Trichocephalus and Ascaris. Buxton (1920) also recorded the natural occurrence in flies of eggs of Hymenolepis nana, Strongyloides, etc.

With regard to the medicinal treatment of parasitic worm infections a few notes only are necessary. The most extensive work on this subject is that of Hall (1919-1920) who has experimentally tested the value of various anthelminthics. Perhaps the most important new treatment is the use of carbon tetrachloride in ancylostomiasis. Results appear to show that this is the most 
efficient drug which has hitherto been employed in the treatment of hookworms, with oil of chenopodium as probably the next best. The use of salvarsan and of antimony tartrate in the treatment of Bilharzia disease is also worthy of note. Railliet (1915) has dealt at some length with the medicinal treatment of diseases caused by Nematodes, and Hall (1917) has called attention to the neglect of medicinal treatment in dealing with veterinary helminthic infections.

I have endeavoured to discuss these various matters as briefly as possible and to allocate to each of them a space approximately proportionate to the amount and importance of the work done. The same plan has been applied to the subjoined list of references which, while omitting a considerable number of important works, will nevertheless, it is hoped, be found to include all the most useful publications up to the end of 1921 together with a few of more recent date.

\section{REFERENCES.}

Batrmann, G. (1917). Ueber Ankylostomiasis, deren Ausbreitungsbedingungen durch die Bodeninfektion und deren Bekämpfung. Geneesk. Tijdschr. Nederl. Indie, LVц. 579669.

Bahr, P. Manson (1912). Filariasis and Elephantiasis in Fiji. Journ. Trop. Med. Suppl. 1. 200 pp.

Bahr, P. Manson and Fairley, N. H. (1920). Observations on Bilharziasis amongst the Egyptian Expeditionary Force. Parasitology, xII. 33-71.

Bang, B. (1913). Strongylose eller Sclerostomiasis hos Fol. Kjobenhawn Mdskf. Dyrl. xxv. 4-24.

Bayuis, H. A. (1920). On the Classification of the Ascaridae. I-II. Parasitology, XIr. 253$264 ; 411-426$.

- (1922). Observations on certain Cestodes of Rats, with an Account of a new Species of Hymenolepis. Parasitology, xiv. 1-8.

Baylis, H. A. and Lane, Clayton (1920). A Revision of the Nematode Family Gnathostomidae. Proc. Zool. Soc. 245-310. 8 Pls.

BEddard, F. E. (1911-15). Contributions to the Anatomy and Systematic Arrangement of the Cestoidea. I-XVIII. Proc. Zool. Soc.

Bedson, S. P. (1913). Lésions des Organes à secrétion interne dans l'intoxication vermineuse. Ann. Inst. Pasteur, xxvIr. 682-699.

Bernard, P. N. and BaUChe, J. (1913). Conditions de propagation de la filariose sous. cutanée du chien. Stegomyia fasciata hôte intermédiaire du Dirofilaria repens. Bull. Soc. Pathol. exot. v1. 89-99.

Bernard, P. N. and BAUChe, J. (1914). Influence du mode de pénétration cutanée ou buccale du Stephanurus dentatus sur les localisations de ce Nématode dans l'organisme du porc et sur son évolution. Ann. Inst. Pasteur, xxvII. 450-469.

Biglieri, R. and ARAOz, J. (1917). Contribucion al estudio de una nueva filariosis humana encontrada en la Republica Argentina (Tucuman) occasiona por la Filaria tucumana. Buenos Aires. 22 pp.

Blanc and Caminopetros (1921). Le Cysticercoïde d'Hemidactylus turcicus Lin. Bull. Soc. Pathol. exot. xrv. 20-21.

BLUм, P. (1911). Histologische Untersuchungen über die Wurmpneumonie des Schafes. Gross-Steinheim a. M. (K. Jung).

Borinr (1914). Pseudo-appendicite da Ascarida. Arch. de Parasitol. xvi. 428.

Boulenatr, C. L. (1916). Sclerostome parasites of the horse in England. Parasitology, vill. 420-439; IX. 203-212. 
Brav, P. (1914). Trichocephalus dispar et dysenterie. Journ. Far Eastern Assoc. Trop. Med. 21-25.

Breinl, A. (1921). Preliminary Note on the Development of the Larvae of Dirofilaria immitis in dog-fleas, Ctenocephalus felis and canis. Ann. Trop. Med. and Parasit. XIv. 389-392.

Brumpt, E. (1919). Une nouvelle Filaire pathogène parasite de l'homme (Onchocerca caecutiens n. sp.). Bull. Soc. Pathol. exot. XII. 464-478.

Bull, L. B. (1919). Contribution to the Study of Habronemiasis. Trans. Roy. Soc. South Australia, xuIIr. 85-141.

Bullock, F. D. and Rohdenburg, S. L. (1918). Experimental Carcinomata of animals and their relation to true malignant tumours. Journ. Cancer Research, ㅍ. 227.

Bullock, F. D. and Rohdenburg, S. L. (1912). Cell Proliferation and Parasites in Rats. Journ. exper. Med. xvi. 527-531.

Buxton, P. A. (1920). The importance of the House-fly as a Carrier of Entamoeba histolytica. Brit. Med. Journ. I. 142-5.

CAvA, LA (1916). Il primo caso auctotone in Europa di Elefantiasi di Filaria bancrofic con adenolinfocele e linfoscroto. Un focolaio di filariosi in provincia de Treviso. Malaria e Mal. de paesi caldi, vir. 221-5.

CAwston, F. G. (1918). The possible intermediate host of Schistosoma in South Africa. Journ. Trop. Med. XXI. 69-70.

Christofrersen, N. (1913). Om Trichocephalus dispar. Dr. Disp. Kjpbenhavn (Arnold Busch). 222 pp.

Christopherson, J. B. (1920). On the action of Tartrate of antimony in intravenous injection; the permeability of Bilharzia ova and some protozoal organisms. Brit. Med. Journ. II. 854.

Cleafye, H. J. van (1918). The Acanthocephala of North American Birds. Trans. Amer. Micr. Soc. Xxxvir. 19-48.

(1919). Acanthocephala from the Illinois River, with a Synopsis of the family Neo-echinorhynchidae. State Illinois Nat. Hist. Survey, XسI. 225-257. 2 Pls.

Clemand, J. Burton (1914). Further Investigations into the Etiology of Worm-nests in Cattle due to Onchocerca gibsoni. Commonwealth Australia, Melbourne. 56 pp. 3 Pls.

Connal, A. and S. L. (1922). The Development of Loa loa (Guyot) in Chrysops silaria (Austen) and in Chrysops dimidiata (Van den Wulf). Trans. R. Soc. Trop. Med. and Hyg. xvi. 64-89.

Cooper, A. R. (1919). North American Pseudophyllidean Cestodes of Fishes. Illinois Biol. Monogr. rv. 295-541.

Cont, W. W. (1919). The Cercaria of the Japanese Blood-fluke, Schistosoma japonicum. Univ. Calif. Pub. Zool. xvII. 485-507. (1919). On the resistance to desiccation of the Intermediate Host of Schistosoma japonicum. Journ. Parasitology, v1. 84-88.

- (1921). The Development of the Japanese Blood-fuke, Schistosoma japonicum in the final host. Amer. Journ. Hyg. I. 1-38.

Cort, Augustin, Ackert, Payne and Payne (1921-2). Investigations on the control of Hookworm Disease. I-X. Amer. Journ. Hygiene, I. 556-568; п. I-16; 17-25; 26-38; $39-50 ; 107-148 ; 149-161 ; 162-187$.

Covredr, Сн. (1915). Cachexia ossea dos equidos-Cachexia verminosa dos equidos -Cylicostomose. Arch. Bras. Med., Rio de Janeiro, v. 323-348.

Deineke, D. I. (1912). Das Nervensystem von Ascaris megalocephala. Eine histologische Studie. St Pétersbourg Trav. Soc. nat., Sect. Zool. xuI. (ii), 103-359.

Dévé, E. (1916). L'échinococcose pulmonaire métastatique. Paris, G. Steinheil, Editeur. $160 \mathrm{pp}$. 
Déví, F. (1918). Le cholepéritoine hydatique et sa membrane d'enkystement. Rev. de Chirurgie, xxxvII. 125-167.

(1918). L'échinococcose de l'Enfant. Arch. de Médecine des Enfants, xxi. 225-245.

Dovthiт, H. (1915). Studies on the Cestode family Anoplocephalidae. Illinois Biol. Monogr. I. 353-446.

Farkley, N. H. (1919). Bilharziasis. Some recent Advances in our Knowledge. Lancet, 1016-1020.

(1919). A preliminary Report on an investigation of the Immunity reactions in Egyptian Bilharziasis. Journ. R.A.M.C. xxxII. 243-267.

FaUré-Frímiet (1913). Le cycle germinatif de l'Ascaris megalocephala. Arch. anat. microsc. Xv. 435-757.

FaUst, E. C. (1917). Life-history Studies on Montana Trematodes. Illinois Biol. Monograph, IV. 1-120. 9 Pls.

- (1919). The Excretory System in Digenea. I-IV. Biol. Bull. xxxvr. 315-344.

(1921). Recent Advances in Parasitology. Trans. Amer. Micr. Soc. XL. 75-88.

Fadst, E. C. and Wassell, C. M. (1921). Preliminary Survey of the Internal Parasites of Man in the Central Yangtze Valley. China Med. Journ. xxxv. 532-56I.

FrBIGER, J. (1919). On Spiroptera carcinomata and their relation to true malignant tumours; with some remarks on Cancer age. Journ. Canver Research, v. 367.

- (1920). Recherches sur le carcinome spiroptérien de la souris blanche et sur la transplantabilité. Compt. rend. Soc. Biol. LxxxıII. 1160-1163.

Flury, F. (1913). Beiträge zur Chemie und Toxicologie der Trichinen. Arch. exper. Path. Leipzig, 164-213.

França, C. (1921). A preliminary Note on Bilharziasis indigenous in Portugal. T'rans. Roy. Soc. Trop. Med. Hyg. xv. 180.

Francaviglia, M. L. (1915). Epilessia reflessa da elmintiasi intestinali (Ascaris lumbricoides). Bol. Acc. (rioenia, xxxiv. 13-17.

Fültebors, F. (1912). Untersuchungen über die chemotaktische Wirkung der Malpighischen Gefässe von Stechmïcken auf Hundefilarien. Centralbl. Bakt. Lxv. 349-352. (1913). Beiträge zur Morphologie und Differential-diagnose der Mikrofilarien. Arch. Schiffs- und Tropenhyg. xvir. Suppl. I. 72 pp.

(1913). Die Filariae des Menschen. Handb. der pathogenen Mikroorganismen. Kolle und Wassermann. $160 \mathrm{pp}$.

(1914). Untersuchungen über den Infektionsweg bei Strongyloides und Ankylostomum und die Biologie dieser Parasiten. Arch. Schiff's- und Tropenhyg. xvir. Beiheft 5, 26-80.

- (1920). Ueber die Anpassung der Nematoden an den Parasitismus und den Infektionsweg bei Ascaris und andern Fadenwürmern des Menschen. Arch. Schiffs- und Tropenhyg. xxIv. 8 pp.

Galli-Valerio, B. (1919). Entwicklungszyklus von Dibothriocephalus latus des Hundes. Ibid. XxIII. 602-5.

GaRIN, C. (1913). Recherches physiologiques sur la fixation et la mode de nutrition de quelques Nématodes parasites du tube digestif de l'homme et des animaux. Ann. Univ. Lyon, Xxxiv. $160 \mathrm{pp}$.

Gurnes, W. A. (1916). Intestinal parasites as cause of appendicitis. Bol. soc. med. de Puerto Rico, xurr. 249-251.

GUERrini (1915). Endozooparassiti dell' intestino e colera (nota statistiche). Pathologica, ix. 169-171; and Morgagni, 1919, 42.

HaLL, M.C. (1919). The adult Taenioid Cestodes of Dogs and Cats and of related Carnivores in North America. Proc. U.S. Nat. Mus. Iv. 1-94.

- (1919-20). Studies on Anthelminthics. I-X. Journ. Amer. Veter. Med. Assoc. VIII-X. 
HaLL, M. C. and Hamitron, H. C. (1918). Investigations on the Composition of Oil of Chenopodium and the Anthelminthic value of some of its constituents. Journ. Pharmacol. and Exper. Therapeut. xI. 231-261.

HaLL, M. C. and WigDoR, M. (1918). An experimental study of Serum Therapy in Trichinosis. Arch. internal Med. xxII. 601-9.

HILL, G. (1918). The Relationship of Insects to parasitic Diseases in Stock. I. The lifehistory of Habronema muscae, H. microstoma and H. megastoma. Proc. Roy. Soc. Vict. XXXI. 11-76.

Huвск, O. (1913). Ueber die pathologische Bedeutung von Helminthen in der Appendix. Dissert., Freiburg-i.-Br. 47 pp.

IhLE, J. E. (1918). Ueber die geographische Verbreitung von Ankylostoma ceylanicum. Centralbl. Bakt. i., LxxxII. 306-8.

Innes, J. A. and Campbeld, A. E. (1914). The Occurrence of Oxyuris vermicularis in the Appendix. Parasitology, vi. 189.

JANICKI, C. and Rosen, F. (1917). Le cycle évolutif du Dibothriocephalus latus. Recherches expérimentales et observations. Bull. soc. Sci. Neuchâtel, xLII. 19-53.

JEGEN, G. (1917). Collyriclum faba (Bremser). Ein Parasit der Singvögel, sein Bau und seine Lebensgeschichte. Zeitschr. f. wiss. Zool. cxvIx. 460-553.

Jiмво, K. (1914). Ueber die Verbreitung einer Art von Trichostrongylus, T. orientalis n. sp. als Darmparasit des Menschen in Japan. Centralbl. Bakt. i., Lxxv. $53-59$.

Johnston, S. J. (1912). On some Trematode parasites of Australian frogs. Proc. Linn. Soc. New South Wales, xxxviI. 285-362. 30 Pls.

- (1917). On the Trematodes of Australian Birds. Journ. R. Soc. New South Wales, L. $187-261$.

Johnston, T Harvey (1912). On the Occurrence of Worm nodules in Cattle-A summary. Proc. Roy. Soc. Queensland, xxmr. 207-231. (1912). Notes on some Entuzoa. Ibid. xxIv, 43-91.

(1918). Notes on certain Entozoa of Rats and Mice. Together with a catalogue of the internal parasites recorded as occurring in Rodents in Australia. Proc. R. Soc. Queensland, xxx. 53-78.

Joy fuX, C. (1920). Cycle évolutif de quelques Cestodes. Recherches expérimentales. Bull. biol. France et Belg. Suppl. II. 216 pp.

Katsurada (1913). Schistosomiasis japonica. Centralbl. Bakt. i., LXXII. 363-379.

KaUtZSCH, G. (1912). Studien über Entwicklungsanomalien bei Ascaris. I. Arch. Zellforsch. Leipzig. vIII. 217-25I.

Kemnitz, G. von (1912). Die Morphologie des Stoffwechsels bei Ascaris lumbricoides. Ibid. VI. 463-603.

KhaLI, M. (1922). A Revision of the Nematode Parasites of Elephants, with a description of four new species. Proc. Zool. Soc. London, June. $75 \mathrm{pp}$.

KттAмURA, K. (1916). Ueber Trichostrongylus orientalis Jimbo, einen weit verbreiterten tierischen Darmparasit des Menschen. Fukuoka Mitteil. med. Fak. Kais. Univ. Kyushiu. II. 1-59.

KNUTH, P. (1912). Untersuchungen über die Lungenwurmseuche des Wildes. Zeitschr. F'orstwiss. Berlin, xLvv. 364-376

Krause, R. (1914). Beitrag zur Kenntniss der Hemistominen. Zeitschr.f. wiss. Zool. cxIr. 93-238.

Lane, Clayton (1915). Artyfechinostomum suffartyfex. A new Echinostome of Man. Ind. Journ. Med. Research, II. 977-983.

(1917). Ancylostoma duodenale as a parasite of Felis tigris. Ibid. v. 210-216.

(1917). Final Report on the Ankylostoma enquiry in the Darjeeling district of India. Ibid. v. 350-385.

Parasitology XIV 
Larde, G. R. (1914). A Revision of the Cestode family Proteocephalidae. Illinois Biol. $M o n o g r a p h$, I. 350 pp. 12 Pls.

Le BAS, G. Z. L. (1922). On the Nature of the Antigen in the Complement fixation Test for Bilharziasis. Journ. Trop. Med. and Hyg. xxv. 49-54.

LeIPER, R. T. (1913). Observations on certain Helminths of Man. Trans. Soc. Trop. Med. and Hyg. VI. 265-297.

- (1916). Observations on the Mode of Spread and Prevention of Vesical and Intestinal Bilharziasis in Egypt with additions to August 1916. Proc. Roy. Soc. Med. IX. $145-172$.

- (1915-18). Researches on Egyptian Bilharziasis. London, Bale, Son and Danielson. 1918. 167 pp. Also Journ. R.A.M.C. xxv. 1, 147, 258; xxvIr. 171; xxx. 235.

LeIPER, R. T. and ATkinson, E. T. (1915). Observations on the spread of Asiatie Sehistosomiasis. Brit. Med. Journ. I. 201-3.

LeIPER, R. T. and INaLIs, V. (1914). Materials for a Bibliography of the Trematode Infections of Man. London, Taylor and Francis. $55 \mathrm{pp}$.

LePeSkin, V. D. (1914). Zur Ovogenese der Zoogonus mirus. Moskva Journ., sect. Zool. soc. nat. II. 1-85.

Liston, W. G. and Soparkar, M. B. (1918). Bilharziasis among animals in India. The lifecycle of Schistosomum spindalis. Ind. Journ. Med. Research, v. 567.

Looss, A. (1911). The Anatomy and Life-history of Agchylostoma duodenale. II. Cairo, Records Egypt. Govt. School Med. Iv. 167-607.

Looss, A. and Kartulis (1913). Die Bilharzia-krankheit. Zoologische und medizinische Teil. In Kolle und Wassermann's Handbuch der pathogenen Mikroorganismen, $40 \mathrm{pp}$.

LöWENSTEIN (1912). Trichodes crassicauda, als Erreger von Papilloma der Blase und Niere. Verh. Ges. D. Naturf. Leipzig, LxxxIrr. 162-6.

LuTz, A. (1919). O Schistosomum mansoni e a Schistosomiasis segundo observaçoes feitas no Brazil. Mem. Ist. Oswaldo Cruz, XI. 121-155.

MagCallum, G. A. and W. G. (1913). Four Species of Microcotyle. Zool. Jahrb. Syst. XXXIV. 245-256.

MaCCALLUM, G. A. (1916). Some new species of parasitic Trematodes of Marine Fishes. Zoopathologica, I. (i.), 37.

Martin, A. (1913). Recherches sur les conditions de développement embryonnaire de Nématodes parasites. Ann. Sci. Nat. (Zool.), Paris (9), xvIII. 1-151.

MartinI, E. (1916). Die Anatomie der Oxyuris curvula. Zeitschr.f. wissen. Zool. cvt. 137-534.

Meinhof, H. (1913). Zur Klinik und Morphologie der Filaria und Mikroflaria loa (diurna). Arch. Schiffs- und Tropenhyg. xvII. Beiheft 2, 58 pp.

Mrta, G. (1918). Beiträge zur Kenntnis der Echinococcus mit besonderer Berücksichtigung des Alveolarechinococcus. Fukuoka Mitt. med. Fak. Univ. Kyushiu, Iv. 156-393.

Mryagawa (1913). Ueber den Wanderungsweg des Schistosomum japonicum dureh Vermittlung der Lymphgefäss-system des Wirtes. Centralbl. Bakt. Lxvir. 204-6.

MLyaIRI, K. and Suzuki, M. (1914). Der Zwischenwirt des Schistosomum japonicum Katsurada. Fukuoka Mitt. med. Fak. Univ. Kyushiu, I. 187-197.

Montel, M. L. R. (1916). Erythème noueux et Ascaridiose intestinale. Bull. soc. méd. chir. Indo-chine, vII. No. 2.

Nakagawa, K. (1916). The Mode of Infection in Pulmonary Distomiasis. Journ. Infect. Diseases, XVIII. 131-142. (1921). On the life-cycle of Fasciolopsis buski. Kitasato Arch. Exper. Med. Iv. 159167.

NaRABAYASHI (1914). On the migratory course of Schistosoma japonicum in the body of the final host. Kyoto Igaku Zasshi, xII. No. 1.

NESHI (1913). Ueber die Entwicklung des Trichocephalus innerhalb des Wirtes. Tokyoer Med. Wochenschr. No. 2080. 
Neveu-Lemaire, M. (1918). Contribution à l'étude des organes reproducteurs et de la reproduction chez les Strongyles dépourvus de capsule buccale. Mém. Soc. Zool. France, XXVII. 5-126.

NICOLL, W. (1914). The Blood-volume in Ankylostomiasis. Journ. of Hyg. XIII. 369-392.

- (1914). On the Migration of the Larvae of Onchocerca gibsoni through the eapsule of the worm-nodule. Ann. Trop. Med. and Parasit. vIII. 609-621.

- (1914-18). The Trematode Parasites of North Queensland. I-IV. Parasitology, vr. $333-350$; vII. 105-126; vIII. 22-41; X. 368-374.

- (1917). Observations on the Influence of Salt and other Agents in modifying the larval development of the Hookworms. Ibid. Ix. 155-189.

Noc, F. (1915). Parasitisme intestinal au Cochin Chine. Contribution à l'étude des dysenteries indo-chinois. Bull. soc. path. exot. vIII. 208-218.

Nyberin, O. (1919). Zur Entwicklungsgeschichte von Schistocephalus solidus. Centralbl. Bakt. LxxxIII. 295-7.

OGATA, S. (1914). Ueber den anatomischen Körperbau der Cercaria des Schistosomum japonicum und die Uebertragungsweise derselben auf Tiere. Verhandl. Japan Path. Gesellschaft Tokio, xLvirI.

OkUmuRa, T. (1919). An experimental study on the life-history of Sparganum mansoni Cobbold. Kitasato Arch. Exper. Med. III. 190-7.

Ouzillead, Laigret et Lefron (1921). Contribution à l'étude de l'Onchocerca volvulus. Bull. Soc. Pathol. exot. xIv. 717-728.

Parisot et Joyedx (1920). Les cysticercoids de Tarentola mauretanica et les Ténias du Chat. Ibid. XIII. 687-695.

Parodi, S. E. and Widakowich, V. (1918). Action traumatica del Strongylus equinus. Riv. Jardin. Zool. Buenos Aires, II. 16-27.

Paulian, D. E. (1918). Parasitisme et Eosinophilie. C. R. Soc. Biol. LxxvIII. 155-6.

Pomelia, C. (1912). Lésions provoquées chez le cobaye par les teniotoxins. Ibid. LxxIII. 445.

Rachmanov (1914). Lésions du système nerveux dans l'intoxication vermineuse. Ann. Inst. Pasteur, Xxvur. 181.

RaILLIET, A. (1915). L'emploi des médicaments dans le traitement des maladies causées par des Nématodes. Réc. méd. vét. Paris, xcI. 490-513.

- (1918). Sur les troubles généraux occasionnés par les Oxyures de Cheval. Bull. Soc. centr. méd. vét. 30th Nov. 450-2. (Bedel, Ibid. 452-8; Donnat, Ibid. 458-464.)

— (1919). L'Onchocercose cervicale et le mal de garrot. Ibid. 1919, 111-116.

Railliet, A. et Henry, A. (1913). Sur les Oesophagostomiens des Ruminants. Bull. soc. Pathol. exot. vi. 506-511. (1915). Le parasite de la dermite granuleuse des Equidés. Ibid. vIII. 695-704.

Railliet, A., Henry, A. et Badche, J. (1914). Sur les Amphistomiens des Ruminants domestiques de l'Annam. Réc. méd. vét. XcI. 195-201.

Ransom, B. H. (1913). The life-history of Habronema muscae Carter, a parasite of the horse transmitted by the house-fly. Bull. 163, Bureau Anim. Indust., U.S. Dept. Agric. $36 \mathrm{pp}$.

- (1916). The Occurrence in the United States of certain Nematodes of Ruminants transmissible to Man. New Orleans Med. and Surg. Journ. Lxix. 294-8.

- (1919). A newly recognized cause of Pulmonary Disease-Ascaris lumbricoides. Journ. Amer. Med. Assoc. LxxIIr. 1210-2.

Ransom, B. H. and Foster, W. D. (1920). Observations on the Life-history of Ascaris lumbricoides. U.S. Dept. Agric. Bull. 817. 47 pp.

Ransom, B. H. and HaLL, W. C. (1917). A further Note on the Life-history of Gongylonema scutatum. Journ. Parasitology, III. 177-181.

Ransom, B. H., Schwartz, B. and Raffensberger, H. B. (1920). Effects of Pork-curing Processes on Trichinae. U.S. Dept. Agric. Bull. 880.37 pp. 
Rhaindorf, A. (1920). Die Wurmfortsatzentzündung. Berlin, S. Karger. 244 pp.

RoBles, R. (1919). Onchocercose humaine au Guatemala produisant la cécité et l'érysipèle du littorale. Bull. Soc. Pathol. exot. XII. 442-463.

Rodenwaldt, E. (1914). Eine neue Mikrofilaria im Blut des Menschen. Arch. f. Schiffsu. Tropenhyg. XVIII. 1-12.

Rodhat et VAN DEN BRAnden (1916). Recherehes diverses sur la Filaria (Onchocerca) volvulus. Bull. soc. Pathol. exot. Ix. 186-198.

Romanovitch and Slavin (1915). Dictyocaulus filaria und die Lungenwurmseuche der Schafe. Arch. veter. nauk. Petrograd, xuvi. 379-391.

Rosen, F. (1918, 1919). Recherches sur le développement des Cestodes. Bull. soc. Neuchâtel de Sci. Nat. XLIII. 1-64; XLv. 1-21.

Roubadd, E. and Descazea dX, J. (1921). Contribution à l'histoire de la Mouche domestique comme agent vecteur des Habronemoses d'Equidés. Bull. soc. Pathol. exot. xIv. 471-506.

RUtz-Arnim (1916). La lymphectasie tropicale primitive. Paris, A. Maloine et fils. 138 pp.

vaN SACEgHEM, R. (1917). Contribution à l'étude de la Dermite granuleuse des Equidés. Bull. soc. Pathol. exot. x. 726; XI. (1918), 575.

SaISAWa (1912). Untersuchungen über Hundefilarien. Centralbl. f. Bakt. Lxvrr. 68-75.

Sḱnechal and Enger (1912). Trois cas d'Appendicite vermineuse. Arch. Parasit. Paris, Xv. 315 .

Sedrat, L. G. (1912). Sur le cycle évolutif du Spiroptère du Chien. C. R. Acad. Sci. cliv. 82-84.

- (1913). Sur l'évolution des Nématodes parasites. C. R. IX Congrès intern, zool. Rennes, 623-643.

_- (1916). Contribution à l'étude des formes larvaires des Nématodes parasites hétéroxènes. Bull. Scient. France et Belg. XuIx. 297-377.

— (1919). Contributions nouvelles à l'étude des formes larvaires des Nématodes parasites hétéroxènes. Bull. biol. de France et Belg. Lrr. 314-378.

- (1920). Histoire naturelle des Nématodes de la Berberie. I. Alger, S. Stamel. 221 pp.

ShIRcore (1916). A note on some helminth diseases with special reference to the house-fly as a natural carrier of the ova. Parasitology, vIII. 239.

Simontn, P. (1922). Rev. méd. de l'Est, p. 314.

SkrJabin, K. I. (1913). Schistosomum turkestanum, nov. sp., ein neuer Parasit des Rindes aus Russisch-Turkestan. Zeitschr. Infektionskrankh. Haustiere, XIII. 457-463.

- (1915). Trématodes des oiseaux de l'Oural. Ann. Mus. Zool. Acad. Imp. Sci. Pétrograd, xx. 395-417.

_ (1917). Loa extraocularis nov. sp., parasite nouveau de l'œil de l'homme. Compt. rend. Soc. Biol. LXxx. 759.

StäUbLt, C. (1913). Trichinose; in Kolle und Wassermann, Handbuch der pathogen. Mikroorganismen, $2^{\text {te }}$ Aufl. vIrT. 75-122.

StewaRT, F. H. (1918). On the development of Ascaris lumbricoides and A. mystax in the Mouse. Parasitology, xix. 189-196.

- (1919). Recent Experiments on the Life-history of Ascaris lumbricoides. Brit. Med. Journ. I. 102; and Trans. R. Soc. Trop. Med. XшI.

STifT, A. (1912). Zur Geschichte der Rübennematoden. Wien. Ost-Ungar. Zeitschr. Zuckerindust. Landw. XI.T. 417-498.

Stiles, C. W. (1920). Index Catalogue of Medical and Veterinary Zoology. Roundworms. Hyg. Lab. Bull. Washington, cxIv. 886 pp.

Stunkard, H. W. (1917). Studies on North American Polystomidae, Aspidogastridae and Paramphistomidae. Illinois Biol. Monogr. III. 114 pp.

SwEET, G. (1915). Investigations into the Occurrence of Onchocerciasis in Cattle and associated Animals in Countries other than Australia. Proc. R. Soc. Vict. xxvIIr. i. 1-51. 


\section{W. NICOLL}

TenhaefF and Ferwerda (1919). On the Occurrence of Taenia echinococcus in the Dog in Friesland. Meded. Veeartsenykund dienst, No. 1.82 pp.

Teppaz (1919). Sur la dermite granuleuse des Equidés. Bull. soc. centr. méd. vét. 470-4.

Travassos, L. DE (1915). Informações sobre os helminthes parasitos do homem encontrados no Brazil. Rio de Janeiro, Typ. do Jornal do Commercia, Rodriguez e C.

- (1913). Sobre as especies brazilianas da subfamilia Heterakinae Railliet e Henry. Mem. Ist. Oswaldo Cruz. $33 \mathrm{pp}$.

Vequid, F. (1915). The Anatomy and Life-History of Haemonchus contortus. Report Director Vet. Research, Union of South Africa, 347-500.

WARD, H. B. and HIRsch, E. F. (1915). The Species of Paragonimus and their differentiation. Ann. Trop. Med. and Parasit. Ix. 109-162.

Whinberg, M. (1913). Die Echinokokken und die Serum-Diagnostik der Echinokokkenkrankheit. Kolle und Wassermann, Handb. d. pathog. Mikroorganismen. 62 pp.

Weinbera, M. and Seguin, P. (1914). Recherches biologiques sur l'éosinophilie. Ann. Inst. Pasteur, xxviIr. 1-39.

Wenyon, C. M. and O'Connor, F. W. (1917). The Carriage of Eggs of Parasitic Worms by House-flies, with some notes on the resistance of cysts to disinfectants and other agents. Journ. Roy. Army Med. Corps, xxvirI. 522.

WinTr, D. (1917). Filariose bei einheimischen Pferden. Zeitschr. f. Infektionskr. Haustiere, XVIII. 380 .

Yokogawa, S. (1920). On the Migratory Course of Trichosomoides crassicauda in the body of the final host. Journ. Parasitol. Urbana, vI. 80-84.

Yokogawa, S. and SUYEMORI (1920). Observations on abnormal courses of infection of Paragonimus ringeri. Ibid. 183-187.

YoRkE, W. and BlackLock, B. (1917). Observations on the Periodicity of Microfilaria nocturna. Ann. Trop. Med. Parasit. xI. 127-147.

YoRke, W. and MACFIE, J. (1918). Strongylidae in Horses. Ibid. xI. 399-416; xIr. 79-92.

Yoshida, S. (1916). On the intermediate hosts of the Lung Distome, P. westermanni Kerbert. Journ. Parasitol. II. 111-118.

(1916). Some Notes on the encysted larvae of the Lung Distome. Ibid. II. 175-180. (1919). On the development of Ascaris lumbricoides. Ibid. v. 105-115.

(1920). A new course for migratory Ankylostoma and Strongyloides larvae after oral infection. Ibid. vIr. 46-48.

ZaChaRIAS, O. (1913). Ueber den feineren Bau der Eiröhren von Ascaris megalocephala insbesondere über zwei ausgedehnte Nervengeflechte in denselben. Anat. Anz. Jena, LXIII. 193-211. 